Elżbieta LESIEWICZ

DOI : $10.14746 / \mathrm{pp} .2020 .25 .4 .5$

\title{
Independence referenda in Catalonia and their political significance
}

\begin{abstract}
The article discusses two independence referenda of 2014 and 2017, which have been declared illegal by the Spanish government and the Constitutional Court. The referenda have shown that the majority of Catalans to establish their own state. The article presents historical conditions of the Catalan independence movement, analysis of referenda outcomes, and the impact of the 2020 pandemic on the independence movement. Methods used include institutional and legal analysis, system analysis and historical genetic method. The methods have proven that to a large extent historical factors and the 2008 economic crisis contributed to independence tendencies in Catalonia. All these facts contributed to the growing support for the independence among Catalans. This has been proven by outcomes of two independence referenda. The first one of them was held on 9 November 2014 and the turnout was 2 million out of 5.4 million eligible citizens. As much as $80 \%$ of voters opted for independence. The turnout of the 2017 referendum was $42.3 \%$ out of 5.34 million, and $90 \%$ of 2.26 million citizens participating in the referendum opted for independence, whereas $8 \%$ were against. The referenda showed that independence trends in European regions were still valid, since separatists might even use the crisis caused by the 2020 pandemic to support they independence struggle.
\end{abstract}

Key words: Catalonia, Spain, independence referenda, separatist tendencies, coronavirus pandemic

$\mathrm{C}$ atalonia is one of 17 autonomous regions in the decentralized Spanish political system established after the death of dictator Francisco Franco in 1975. The region has its own government, president and a parliament. Nevertheless, a vast majority of Catalonians are dissatisfied and want to sever ties with Spain based on their right of self-determination. These trends were expressed in independence referenda held in Catalonia in 2014 and 2017. The separatist trends made worsened relations between Catalonia and Spain. The main goal of the article is to examine Catalonian independence referenda of 2014 and 2017. The referenda were held contrary to the decision of the Spanish government and the ruling of the Constitutional Court, since both institutions declared the referenda to be illegal. Another major goal was to determine reasons underlying the referenda and possible consequences of their results for Catalonians and Spaniards. The research goal was implemented by the institutional and legal analysis which enabled to examine direct democracy legal solutions in Spain. Other methods that also proved useful included the system analysis and the historic genetic method. Both of them supported the analysis of Catalan independence movements in the past centuries. Motives to consider the topic included its current validity and the fact that referenda have become a popular tool used in the decision-making process in contemporary Europe. 


\section{Historical development of the Catalonian independence movement}

In order to analyse the Catalonian independence movement, we need to examine historical conditions dating back to the $10^{\text {th }} \mathrm{c}$., a period of the Reconquista and the liberation of the Iberian Peninsula from the Moors. The process took nearly 700 years with Grenada liberated last in 1492. It was the time when a number of feudal states were created. The most important of them included the Kingdom of Navarre, Kingdom of Aragon, and the County of Barcelona. In the $18^{\text {th }} \mathrm{c}$., Spain was politically united. However, cultural, language and the sense of differences remained in, for example, Catalonia and Aragon (Szul, 2015, p. 14).

In the light of the above mentioned facts, Catalonia did not have much experience in operating as an independent state. There was, of course, the medieval County of Barcelona, but it was merely a feudal ephemeral entity. The nationalist movement or the ethnic regionalism started growing in the $19^{\text {th }} \mathrm{c}$. Then, following the spirit of romanticism in Europe and independence movements, Catalonia welcomed the Renaixença, or cultural renaissance. Catalonia witnessed a growing interest in the Catalan language, literature developed in the language, Catalan became standardised (harmonization of grammar, spelling, etc.). The Catalan language became an important symbol of the Catalan identity and longing for their own culture and the possibility of using the language. This was the beginning of the Catalonism, a political movement designed to win the recognition for Catalans as a sovereign nation (Kozłowska-Socha, 2014, p. 186).

In the $20^{\text {th }} \mathrm{c}$., Spain struggled against conflicting centralist and separationist (regionalist) tendencies. They were very vivid during the Republic, when three regions became autonomous: the Basque Country, Catalonia and Galicia. Then, during General Franco's dictatorship, centralism prevailed and any signs of regionalisms were persecuted, including such areas as culture and politics. For example, the authorities banned the use of any other languages than Spanish in schools and in public. After Franco's death, the democratic process started to develop and one of its components was regionalisation and decentralisation of the state (Husar, 2014, pp. 49-50). On 27 December 1978, Spain adopted its Constitution. Its overriding principle was that "the Constitution is based on the indissoluble unity of the Spanish nation, joint and indivisible homeland of all Spanish people, and the recognition of the right to autonomy of constituent peoples and regions and the solidarity between them." However, the current territorial division of the Kingdom of Spain was not determined by the Constitution, but relevant statutory autonomy and rulings of the Constitutional Court (Myśliwiec, 2006, p. 55). This led to the establishing of 17 regions, provinces of different population, surface area, and economic development. Catalonia regained its political autonomy and the region adopted its previous name of Generalitat de Catalunya.

In 1979, the 57-clause Statutes of the autonomy were adopted. According to the Statutes, both Catalan and Spanish were official languages of the autonomy and the state. The government of Catalonia enjoyed exclusive competences as regards local institutions, amendment of civil law, spatial management, economic and agricultural policies, protection of cultural heritage, tourism, and transport. The Parliament of Catalonia (Generalitat) represents the legislative branch. It is elected through universal, free, equal, direct, and secret voting for a 4-years term of office. Its main tasks include the monitoring 
of the government of the autonomy and approval of the budget. The executive branch is represented by the government headed by the president. The president is elected by the parliament from among deputies and appointed by the king. Executive and administrative functions are also performed by the Executive Council of Catalonia. Other clauses regulate relationship between state and autonomy bodies, chiefly in economy and finance. Statutes of autonomous communities gave regions much independence, and at the same time maintained the integrity of the state. All rights not reserved for the central government were designated to regions. Thus, regional communities became a certain kind of small states having their own anthems, emblems, flags, languages, division of power with broad competences that re not contradictory to the overall idea of The Kingdom of Spain. These instruments gave Catalonia an opportunity to cherish and develop their own culture and decide about their own peoples, provided this does not contradict the interests of the State (Historyczne podstawy...).

However, the government of Catalonia was not satisfied with the Autonomy Statutes established in 1979. The amendment of the document was developed by a special committee of the Catalan Parliament. The amendment had the following goals: raising awareness of Catalonia as a separate nation in Spain; increase in the level of self-governance Catalan institutions and higher level of protection secured by the Constitutional Court to oppose regular interventions of the central government; improvement of the unfavourable system of public finance which caused deficit of 7-8\%. The final version of the statutes was the result of negotiations between Catalan parties and the Spanish government. In 2006 , Catalans adopted the statutes in a referendum by $78 \%$ majority and with the turnout of 48\% (Jackiewicz, 2013, pp. 406-407).

In 2010, the Spanish Constitutional Court declared the majority of changes to be not in line with the constitution, and consequently the wording of the Statutes was brought back to its version before 2006. Catalans did not respect the ruling what was expressed in mass demonstrations. In June 2010, the demonstrations in protest of the Court's decision had their peak. At that time, one fourth of the society supported a complete independence from Spain (Walka Katalonii...). Not only was the Statutes a reason of political tensions, and every month brought another contentious issue between Madrid and Barcelona. On the one hand, Catalan media used every opportunity to prove the anti-Catalan attitude of the Spanish government and emphasised the need to continue the struggle, whereas, on the other hand, Spanish media did the same to condemn the self-centred approach and separatist trends in Catalonia. This translated into a growing antagonism. Spain boycotted Catalan products (Gregulska, 2017) and Catalonia was a site of major protests which peaked on 10 July 2010. Òmnium Cultural, an association promoting Catalan language and identity, organised a march of Som una nacio. Nosaltres decidim, or "We are the people. We are to decide" involving 1.5 million people. The majority of political parties in Catalonia supported the idea (Mora, 2013).

\section{Referendum of 2014}

After the 2010 election, Catalonia was governed by Artur Mas who agreed for street protests to be organised to promote independence in the region. On 11 September 2012, 
on the $298^{\text {th }}$ anniversary of conquering Barcelona by Philip V, large protests took place in the centre of Barcelona involving between 600 thou. to 1.5 million people who came to the capital of the region from all over Catalonia. Their motto was "Catalonia - a new state in Europe." While celebrating the National Day of Catalonia, A. Mas concluded that "the time has come to create state structures in Catalonia." This caused much concern in the central government in Madrid. The Spanish government, headed by Prime Minister Marian Rajoy, rejected Catalan postulates to establish a "fiscal autonomy" in the region. ${ }^{1}$ Then, on 25 September 2012, since the government in Madrid was adamant about the situation, A. Mas requested Catalans to assess the policy of his autonomous government. And so the election of the new Catalan parliament was scheduled for 25 November 2012 (two years before the end of the term of office). The election was a kind of vote of approval for the executive branch, and at the same time a quasi-referendum on the independence from Spain (Hankus, 2014, p. 217).

In November 2012, the early election was held to the Catalan Parliament. Finally, the Artur Mas' party Convergence and Union (CiU) won the election and got 50 seats in the 135-seat parliament, 12 less than in the 2010 election. The election was a painful failure for the United Socialist Party of Catalonia (Partit Socialista de Catalunya, PSC) which won 20 mandates, 8 less than in 2010. The Popular Party (Partit Popular de Catalunya, PPC) won 19 mandates, one more than previously. The Green (Iniciativa de Catalunya, ICV-EUiA) won 13 mandates, and "Citizens" (Ciutadans) 9 mandates. CUP, an association of radical leftist separatist groups, won 3 seats in the parliament. However, the big winner of the election was the Republican Left of Catalonia (ERC), a party which also wanted to sever ties with Madrid. The party won as many as 21 seats in the new parliament, twice more than in 2010 (Separatyści wygrali...).

Finally, on 18 December 2012, CiU and ERC agreed and formed a new coalition government. A condition set by the ERC was to specify a date for a referendum in the bilateral coalition agreement. On 23 January 2013, the two main political groupings fighting got the independence of Catalonia, i.e. the leftist ERC and rightist CiU - overcame historical antagonisms and filed a motion. Based on the motion, the Catalan parliament decided that the "Catalonia is a sovereign political and legal entity." It was, in fact, a declaration of independence. Moreover, on 11 April 2013, the same parliament established the Advisory Council for the National Transformation. Its task in 2014 was to organize a referendum on self-determination and revise suitability of Catalonia to become independent in all possible spheres (Mora, 2013).

Their support for independence was expressed by La Via Catalana (Catalan Road), a $400 \mathrm{~km}$ chain of people holding hands, organised by the Assemblea Nacional Catalana (ANC) on the occasion of the National Day of Catalonia on 11 September 2013. This large independence manifestation involved roughly over a million people. At that time, the support for independence was high (48.5\%). Although the growing independence movement opted for it, the organisation of an official referendum was little realistic. Therefore, the local Parliament decided to hold an election consultation on 9 November 2014. It was organised against the will of the Madrid government and the decision of

${ }^{1}$ The goal of "fiscal sovereignty" requested by Catalonia was to acquire competences to collect taxes. Taxes supposed to be collected by local governments and only then their part transferred to Madrid. 
the Constitutional Court. A question asked in Catalan, Spanish and Occitan ${ }^{2}$ was "Do you want Catalonia to be a state?" (yes/no), and if yes, "Do you want Catalonia to be an independent state?" (yes/no).

\section{CONSULTA SOBRE EL FUTUR POLITIC DE CATALUNYA 2014 CONSULTA SOBRE EL FUTURO POLITICO DE CATALUÑA 2014}

Vol que Catalunya esdevingui un Estat? ¿Quiere que Cataluha sea un Estado?

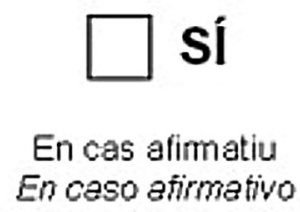

Vol que aquest Estat sigui independent? ¿Quiere que este Estado sea independiente?

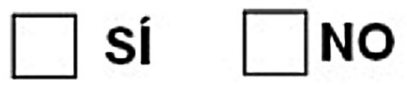

$\mid$

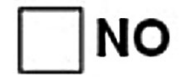

Fig. 1. Ballot paper. Consultation on the political future of Catalonia 2014

Source: El País, https:/elpais.com/politica/2014/09/27/actualidad/1411818191_687352.html, 27.10.2019.

The consultation turnout was $37 \%$, or over two million voters, of whom $81 \%$ were for an independent state, $10.7 \%$ for a federation with Spain, and $4.45 \%$ rejected any changes (Kluczowe fakty na rzecz referendum).

On 27 September 2015, another election was held. They had a form of a plebiscite, since another official referendum was not possible. Two weeks before the election, over a million people protested on 11 September, the National Day of Catalonia. From June to October, the support for independence increased from $37.6 \%$ to $41.1 \%$. According to official results, the Together for Yes won 62 mandates in the parliament, whereas their leftist ally the Peoples Unity Candidature (CUP) 10. In total, the two political groupings won 47.33 percent of votes. The total number of eligible voters was over 5 million (Katalonia zmierza ku niepodległości...).

In November 2015, the Catalan parliament adopted a declaration which announced that within a year and a half "democratic, methodical and peaceful separation from Spain would start," which was the announcement of the republic. The declaration also renounced allegiance to the government in Madrid. Since 2015, the majority of political groupings in the Catalan parliament supported independence. The independence coalition won the election of 2015. Their priority was to hold an independence referendum (Dramatyczny przebieg referendum $w$ Katalonii...).

${ }^{2}$ According to the 2006 Statutes, Occitan is one of three official languages in the Autonomous Community of Catalonia next to Catalan and Spanish. 


\section{Referendum 2017}

On 6 October 2016, the Catalan parliament adopted a resolution on holding of the independence referendum. Deputies representing Junts pel Sí and CUP voted for the resolution, whereas Catalunya Sí que Es Pot abstained. MPs from Ciudadanos, PSC and PPC resigned from voting. The referendum was to be held by 17 September 2017 at the latest (Catalan Parliament Votes Yes...). Thus, the referendum became mandatory even in case of objection on the part of the Spanish central government (Parliament approves calling a referendum...). As expected, the resolution was repealed by the Constitutional Court in December 2016. On 9 June 2017, Carles Puigdemont, the Premier of the government, announced that on 1 October 2017 the referendum would be held and citizens would answer a question in Catalan, Spanish and Occitan whether they desired Catalonia to become an independent republic (El president Puigdemont...; El Govern convoca la votación...).

The draft resolution was discussed by the Catalan parliament on 9 September and was adopted by the majority of 72 votes. At the same time, 52 opposition MPs left the chamber to protest against the manner in which the document was submitted and discussed (El Govern convoca la votación...).

To mobilise Catalans, the independence coalition invested much resources and was busy attracting people to the idea. They used all sorts of public events which transformed into independence endorsement gatherings. They used cultural events, commemoration events related to the Catalonia's history, as well as sport events, the symbolic FC Barcelona soccer matches including. Each event attracted crowds of supporters who brought Catalan flags and other symbols and banners with independence slogans. According to the orchestrators, the desired result of the referendum meant that the Republic of Catalonia would be automatically established together with its institutions (Sytuacja skrajnie poważna...).

From the beginning of the referendum campaign, the government in Madrid argued that the referendum was illegal and unconstitutional. Spanish Prime Minister Mariano Rajoy prepared an action plan to counteract separatists. The plan included a forceful prevention of the referendum. On 7 September 2017, the Constitutional Court declared the referendum resolution of the Catalan Parliament illegal. Then, the General Prosecutor's Office issued an order to confiscate all materials, including ballot papers, ballot boxes and any other relevant documentation. The Prosecutor and the Ministry of Finance blocked bank accounts of the Catalan government to stop financing of the referendum. On 20 September 2017, while acting on the order of the Prosecutor's Office, Guardia Civil and State Police proceeded with mass search in ministries responsible for referendum logistics and secured $80 \%$ of materials and documents designated to be used in polling stations. They also arrested Catalan officers responsible for the organisation of the referendum. Despite the prosecutor's action, Catalan Premier Carles Puigdemont continued the referendum campaign. For this reason, upon the request of the General Prosecutor, the Madrid-based Ministry of Internal Affairs decided to appoint a coordinator of special security forces in Catalonia who was to supervise the autonomous Catalan police. Additional police detachments of 3 thousand police officers were also deployed (Sytuacja skrajnie poważna...) 
On 1 October 2017, Catalonia held the independence referendum. Catalans were asked to answer one question: Do you want Catalonia to become a republic?

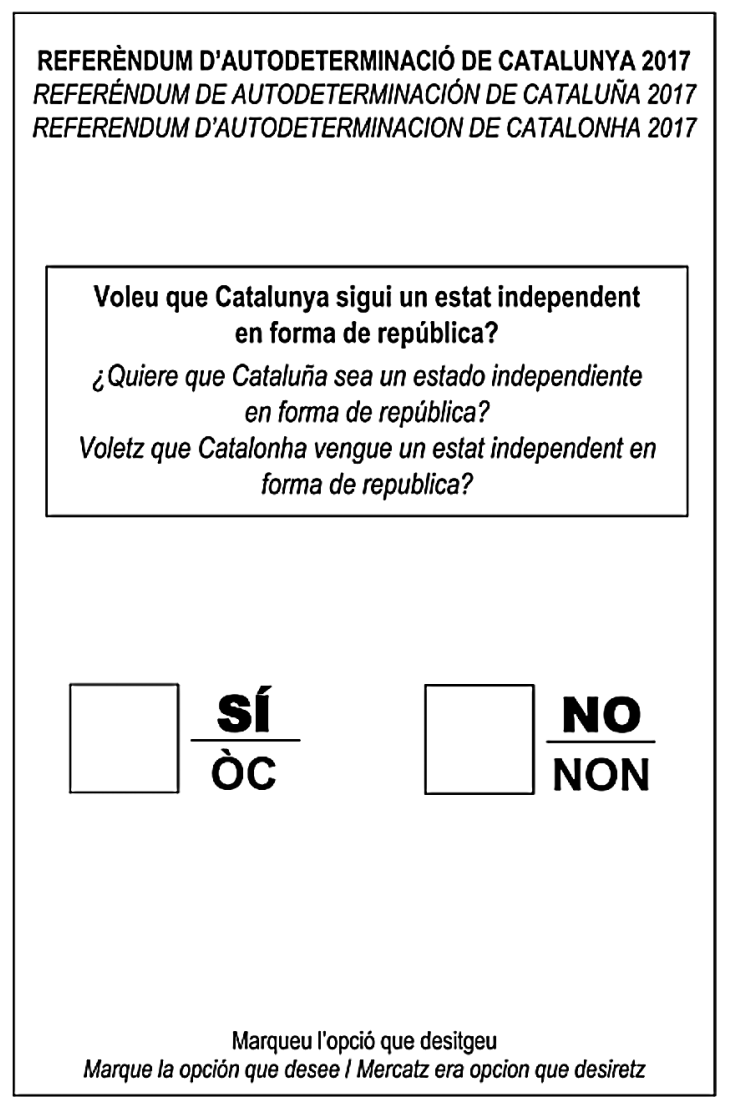

Fig. 2. Ballot paper

Source: El País, https://cat.elpais.com/cat/2017/09/07/catalunya/1504765917_377577.html, 27.10.2019.

During the declared illegal referendum, votes clashed with the police. Spanish Guardia Civil used rubber bullets against rioters, bullets which are banned in Spain. This was heavily criticised by Spanish citizens. The turnout was only 2.28 million out of 5.3 million eligible voters. Ninety percent of voters, or $27 \%$ of Catalonia's inhabitants or $38 \%$ of all eligible voters voted in favour of the independence. On 10 October 2017, Catalonian Prime Minister Carles Puigdemont announced that he "accepted the mandate" given to him by citizens to proclaim independence. At the same time, he asked Catalonian MPs to postpone the secession for the period of negotiation with the Madrid-based government (Katalonia chce niepodległości....). He also signed a symbolic declaration of independence calling other countries to recognize the "Republic of Catalonia."

On 27 October 2017, the unilateral declaration of independence was voter by the Catalonian parliament. There were 70 votes in favour out of 135 member of parliament, 
10 voted against, and 2 abstained. Representatives of opposition parties boycotted the voting (Maseeal, Barrena, 2017). C. Puigdemont admitted that the announcement of the unilateral declaration of independence (DUI) by the Catalan government on 27 October aimed at forcing the Rajoy's government to negotiate with the regional government in Barcelona.

In response to the announcement of the independence, the central government in Madrid suspended the autonomy of Catalonia. Based on Article 155 of the Spanish Constitution, Mariano Rajoy called off the head of the Catalonian government Carles Puigdemont, his cabinet and over 130 high ranking officers in Catalonia. At the same time, a date was set for an early parliamentary election in Catalonia The election held on 21 December 2017 was won by separatist parties: Together for Catalonia (JxC), Republican Left of Catalonia (ERC), People Unity Candidature (CUP). The three political groupings won 70 out of 135 seats in the parliament. Parties supporting the integration of Catalonia and Spain won 57 mandates. The turnout was $81.94 \%$, whereas during the October independence referendum it was $43.03 \%$ (Katalońska deklaracja o niepodległości zawieszona...).

Due to the threat of detention, the former Catalonian Premier Carles Puigdemont fled to Belgium and then Germany, were he was arrested in early 2018. Then, a German court rejected the Spanish request to extradite the Premier. Other organisers of the referendum were declared rebels and detained (Premier Katalonii Carles Puigdemont ścigany nakazem aresztowania). This led to major protests, and thousands of Catalonians went to streets to demand "Freedom for political prisoners" (Setki tysięcy osób na ulicach Barcelony. Domagaty się uwolnienia więźniów politycznych).

From the suspension of the autonomy, the central government took over control of the region. From that moment on Catalonia has not had its own government, since nationalists could not agree between themselves who should take the lead in the region after the December parliamentary election. They tried to push forward the candidature of Puigdemont or his colleagues several times, regardless the fact that they were either detained, on trial or fled abroad like the Prime Minister himself (Katalonia ma premiera. Parlament w Barcelonie przeglosowat kandydature secesjonisty Quima Torry).

With the suspension of the autonomy, the popularity of Catalonia's sovereignty dropped. A survey of January 2018 showed that the support for the idea declined from $48.7 \%$ still in October to $40.8 \%$, whereas the approval for the current status increased from $27.4 \%$ to $36.3 \%$ (See Skorzycki, p. 139). At the same time, the Spanish courts limited possibilities for key Catalonian politicians by pressing charges against 13 Catalonian leaders in March 2018. They were accused of rebel and faced sentences of 25 to 30 years (ibidem, p. 41 ).

Several months later, on 15 May 2018, the Catalonia's parliament elected a new prime minister. The position went to Quim Torra. The candidature won the support of Together for Catalonia (Junts per Catalunya), the election campaign group of the previous prime minister Carles Puigdemont, as well as Republican Catalonian Left (ERC) (Quim Torra zostat nowym premierem Katalonii). The sworn-in ceremony for the new Catalonia's government ended a period of a direct control of the region by the Spanish government. During the ceremony, the new head of the Catalonian Generalitat declared to continue efforts in support of the independence of the region (Rzad Katalonii zaprzysiężony...). 
In May 2018, the conservative Spanish government headed by Prime Minister Mariano Rajoya lost majority in the parliament, and on 1 June, Pedro Sánchez, the leader of the socialist party, was appointed a new prime minister thanks to the support of Catalan separatists (Hiszpania ma nowego premiera).

Despite calls from the separatist movement to hold another referendum, the public in Catalonia were divided as regards the status of the region. In September and October 2018, thousands of supporters and opponents of independence went to streets (Pawłowski).

In October 2019, the Spanish Supreme Court sentenced 9 Catalonian separatists to 9 and 13 years in prison for incitement to an illegal independence referendum. The ruling boosted independence trends in Catalonia. Quim Torra, the Prime Minister of the Catalonia's autonomous government, intensified his efforts to organise another referendum in reaction to the court sentences ( $W$ Katalonii: Konieczne drugie referendum $w$ sprawie niepodległości regionu). He also called the Spanish government to resume talks. However, Premier Pedro Sánchez refused and raised arguments that such a referendum was in breach of the Spanish law (Quim Torra: Spain's top court bans Catalonia leader from office).

\section{Separatist rhetoric and the health crisis in Catalonia}

The 2020 global health crisis due to the Covid 19 pandemic forced the Spanish government to face their own limitations. At the same time, it revealed weaknesses of the political and administrative cohesion of the state. This led to tensions between the central government and the government of Catalonia as regards counteracting of the pandemic (Berumen). This coincided with clashes between two main parties which supported the separatist idea: Junts per Catalunya and Esquerra Republicana de Catalunya. The latter, however, was in support of a dialogue with Madrid, while position of Junts was more confrontational (Berumen, Separatist rhetoric and health crisis). This reduced the support for Catalonia's independence, and according to opinion polls of 21 July 2020 separatist parties had $42 \%$ support, and $50.5 \%$ of Catalonians were against cessation (Catalan president banned from office for 18 months...).

However, Catalonian separatists did not give in and tried to use the coronavirus crisis as anew argument in their fight for independence. They claimed that if Catalonia had been independent, it would have been better prepared to react fast and there would have been fewer deaths (Faus). During the pandemic, separatists accused Madrid of using Covid 19 in their "covert effort to centralise the state" (Musseau).

Despite the pandemic, in 2020, Catalonians celebrated their national holiday on 11 September. However, limitations imposed due to coronavirus reduced the scope of La Diada festivity. For the first time, members of the Catalonian government did not participate in the public gathering. Q. Torra officially laid flowers at the monument of Rafael Casanova, a hero of the 1714 siege of Barcelona. All major events were decentralised to avoid crowds (Catalonia celebrates National Day...). During La Diada, extreme health protection measured were introduced. The National Assembly of Catalonia (ANC), ${ }^{3}$ the organis-

${ }^{3}$ The National Assembly of Catalonia (Assemblea Nacional Catalana) is a bottom-up homogeneous organisation designed to promote independence of Catalan people by using democratic and 
ers of protests, resigned from large protests and called to organise 131 smaller events in 82 communes instead. Number of protesters was limited, and the largest protest was held in Barcelona involving 1700 people. The events attracted 200 to 300 people each, and every participant had to register in advance (Pro-independence protests across Catalonia...). During the health crisis, the separatist bottom-up organisation Committees for the Defence of the Referendum (CDR) encouraged people to protest on their balconies by displaying national symbols of Catalonia (Catalan separatists use coronavirus crisis to...).

\section{Summary}

The considerations included in the article have led to the following conclusions. In the second half of the $20^{\text {th }} \mathrm{c}$., Europe witnessed a growing significance of direct democracy and referenda as a way for citizens to decide by voting. A good example of the above are the independence referenda held in Catalonia. At the same time, it should be emphasised that these were unilateral referenda. The Spanish government denounced them since according to the international law and political practice, no one has the right to declare a single-sided independence, especially when the minority living in a given territory enjoys the right of self-determination, does not suffer discrimination or infringement of their identity, unfair distribution of good, and no one violates human rights. In 2014, Catalonia held an unofficial referendum and its organisers declared a consultative nature of the process. They refrained from using the term independence referendum, and instead they refer to it as the "process of civic participation" in deciding on the future of Catalonia (Czapiewski 2017, p. 103). The referenda of 2014 and 2017 expressed independence trends among Catalonians. Their ambitious goals were culture and language based, economic and symbolic. Catalonians used their broad autonomy to build their identity on the foundations of rich Catalonian culture and language. Catalonians desired to be recognised as a separate nation. It was expressed in the preamble to the Statutes of the autonomous region of Catalonia, statutes which were rejected by the Spanish parliament and the Constitutional Court. One of the key arguments for the separation from Spain was finance, since Catalonia contributes 19\% of Spanish GDP and accounts for $25 \%$ of country's export. Therefore, Catalonians are convinced that the region pays too much to the Spanish budget getting little in return. The economic crisis of 2008 significantly boosted the independence movement in Catalonia. This gave raise to political and cultural groupings in Catalonia which stressed the need of independence and rejected the belt-tightening policy. This increased the popularity of the idea of independence among Catalonians. And two independence referenda were the best prove of the above. On 9 November 2014, the first non-binding referendum was held, which attracted 2 million people out of 5.4 million eligible voters. As much as $80 \%$ voted in favour. Then, the 2017 referendum involved $42.3 \%$ of 5.34 million eligible voters. This time, $90 \%$ of 2.26 million participating citizens voted in favour of the independence, and $8 \%$ against. The referenda showed that independence trends in European regions were still valid. Even

peaceful measures. The ANC is independent from any political organisations and funded from membership fees. This enables the organisation to maintain political and economic independence from political parties and government. 
the 2020 pandemic did not stop Catalonian separatists. They actually used the pandemic as an argument for Catalonia's independence from Spain. They claimed that if Catalonia could have acted independently, the country would have been better prepared to fight the Covid-19 pandemic.

\section{Bibliography}

Berumen R. Separatist rhetoric and health crisis: Spanish regional identities and their political rhetoric in the face of COVID-19, http://www.lejournalinternational.info/en/le-discours-separatisteet-la-crise-sanitaire-les-identites-regionales-espagnoles-et-leurs-discours-politiques-face-aucovid-19\%E2\%80\%A8/, 20.09.2020.

Catalonia celebrates National Day under Covid-19 restrictions - live updates, https://www.catalannews.com/politics/item/catalonia-celebrates-national-day-under-covid-19-restrictions-liveupdates, 24.10.2020.

Catalan separatists use coronavirus crisis to argue for independence, https://www.reuters.com/article/ us-health-coronavirus-spain-catalonia-idUSKBN22B2AW, 20.10.2020.

Catalan president banned from office for 18 months and fined for disobedience, https://murciatoday.com/ catalan-president-banned-from-office-for-18-months-and-fined-for-disobedience_1510295-a. html, 22.10.2020.

Catalan Parliament Votes Yes to Independence Referendum Next September, https://www.voanews.com/ europe/catalan-parliament-votes-yes-independence-referendum-next-september, 28.09.2020.

Czapiewski T. (2017), Demokracja bezpośrednia wobec dążeń separatystycznych. Rozważania nad kategoria referendum niepodległościowego, „Przegląd Politologiczny”, $\mathrm{nr} 2$.

El president Puigdemont, el vicepresident Junqueras i el conseller Romeva explicaran al Parlament Europeu el referèndum que Catalunya celebrarà aquest 2017, http://premsa.gencat.cat/pres_ fsvp/AppJava/convocatoriavw/132559/ca/president-puigdemont-vicepresident-junquerasconseller-romeva-explicaran-parlament-europeu-referendum-catalunya-celebrara-2017.do, 12.02.2019.

El Govern convoca la votación del 1-O tras aprobar la ley del referendum, http://www.elmundo.es/cat aluna/2017/09/06/59af0a25e2704e4a0b8b46f1.html, 12.09.2020.

Faus J., Catalan separatists use coronavirus crisis to argue for independence, https://www.reuters.com/ article/us-health-coronavirus-spain-catalonia-idUSKBN22B2AW, 28.10.2020.

Dramatyczny przebieg referendum $w$ Katalonii. Wzrosła liczba rannych, trwa liczenie głosów, http://wiadomosci.gazeta.pl/wiadomosci/7,114871,22450698, katalonczycy-staneli-w-kolejkach-do-urn-hiszpanski-rzad-probuje.html, 18.09.2020.

Gregulska J. (2017), Raport z okupowanego kraju, „Tygodnik Powszechny”, https://www.tygodnikpowszechny.pl/raport-z-okupowanego-kraju-139350, 18.09.2020.

Historyczne podstawy ksztattujące autonomię Katalonii i Kraju Basków, http://www.psz.pl/168-archiwum/historyczne-podstawy-ksztaltujace-autonomie-katalonii-i-kraju-baskow, 18.09.2020.

Hankus P. (2014), Rok 2014 czasem katalońskiego referendum, „Dyplomacja i Bezpieczeństwo”, nr 1.

Hiszpania: grzywna dla b. premiera za referendum z 2014 r. https://www.bankier.pl/wiadomosc/Hiszpania-grzywna-dla-b-premiera-Katalonii-za-referendum-z-2014-r-4011879.html, 18.09.2020.

Hiszpania ma nowego premiera, https://www.newsweek.pl/swiat/polityka/pedro-sanchez-zaprzysiezony-jako-premier-hiszpanii/pxy1150, 29.11.2020.

Husar W. (2014), Decentralizacja niesymetryczna Hiszpanii - implikacje polityczne i ustrojowe, „Analles", vol. XXI, 2.

Jackiewicz A. (2013), Kontrowersje konstytucjonalonoprawne i polityczne wokół ustroju terytorialnego Królestwa Hiszpanii, in: Aktualne problemy reform konstytucyjnych, ed. S. Bożyk, Białystok. 
Katalonia chce niepodległości, https://www.tvn24.pl/raporty/katalonia-chce-niepodleglosci,1222, 19.10.2020.

Katalonia ma premiera. Parlament w Barcelonie przegłosowata kandydaturę secesjonisty Quima Torry, https://wyborcza.pl/7,75399,23398351, katalonia-ma-premiera-parlament-w-barcelonieprzeglosowal-kandydature.html, 23.10.2020.

Katalonia zmierza ku niepodległości. Zwolennicy odtaczenia od Hiszpanii zdobyli większość w wyborach lokalnych, https://www.tvp.info/21825813/katalonia-zmierza-ku-niepodleglosci-zwolennicy-odlaczenia-od-hiszpanii-zdobyli-wiekszosc-w-wyborach-lokalnych, 19.09.2020.

Katalońska deklaracja o niepodległości zawieszona przez Trybunat Konstytucyjny, https://www.polskieradio.pl/5/3/Artykul/1906365,Katalonska-deklaracja-niepodleglosci-zawieszona-przezTrybunal-Konstytucyjny, 20.09.2020.

Kataloński parlament zagłosowat za odłaczeniem się od Hiszpanii. Jest reakcja Madrytu, http://wiadomosci.radiozet.pl/Swiat/Hiszpania-Parlament-Katalonii-zaglosowal-za-niezaleznoscia-odMadrytu, 20.09.2020.

Katalonia: zwolennicy niepodległości góra $w$ wyborach regionalnych, http://www.lewica.pl/?i$\mathrm{d}=31742$ \& tytul=Katalonia:-Zwolennicy-niepodleg $\% \mathrm{C} 5 \% 82 \mathrm{o} \% \mathrm{C} 5 \% 9 \mathrm{Bci}-\mathrm{g} \% \mathrm{C} 3 \% \mathrm{~B} 3 \mathrm{r} \% \mathrm{C} 4 \%$ 85-w-wyborach-regionalnych, 20.09.2020.

Kluczowe fakty na temat referendum, http://www.barcelonacheckin.com/pl/r/barcelona_przewodnik/ artykuly/zrozumiec-katalonski-ruch-niepodleglosciowy, 28.09.2020.

Kozłowska-Socha Z. (2014), Krajobraz historyczno-polityczny separatystycznej Katalonii, „Studia z Geografii Politycznej i Historycznej”, vol. 3.

Masreal F., Barrena X. (2017), Un Parlament fracturado declara la independencia tras una votación secreta, http://www.elperiodico.com/es/politica/20171027/parlament-declaracion-independencia-cataluna-6383895, 28. 09.2020.

Mora J.-S. (2013), Katalonia na drodze do niepodległości, http://monde-diplomatique.pl/LMD92/index.php?id=1_3, 28.09.2020.

Musseau F., En Catalogne, la double bataille contre le Covid-19 et contre Madrid, https://www.liberation.fr/planete/2020/04/24/en-catalogne-la-double-bataille-contre-le-covid-19-et-contremadrid_1786269, 14.10.2020.

Myśliwiec M. (2006), Katalonia na drodze do niepodległości, Bytom.

Parliament approves calling a referendum with or without Spani s consent, http://web.archive.org/ web/20170817034451/http:/www.catalannews.com/politics/item/parliament-approves-calling-a-referendum-with-or-without-spain-s-consent, 28.12.2020.

Pawłowski M., Perspektywa wyborów parlamentarnych w Hiszpanii w kontekście kryzysu w Katalonii, https://pism.pl/publikacje/Perspektywa_wybor_w_parlamentarnych_w_Hiszpanii_w_kontek_ cie_kryzysu_w_Katalonii, 20.01.2020.

Premier Katalonii Carles Puigdemont ścigany nakazem aresztowania, https://wyborcza.pl/ 7,75399,22602978,premier-katalonii-carles-puigdemont-scigany-europejskim-nakazem.html, 24.03.2020.

Pro-independence protests across Catalonia amid coronavirus concerns, https://www.catalannews. $\mathrm{com} /$ society-science/item/pro-independence-protests-across-catalonia-amid-coronavirus-concerns, 12.10.2020.

Rząd Katalonii zaprzysiężony. Zapowiedź dalszych starań o niepodległość, https://tvn24.pl/swiat/ katalonia-rzad-zaprzysiezony-koniec-bezposredniego-nadzoru-madrytu-ra841985-2580427, 23.09.2020.

Separatyści wygrali wybory w Katalonii (2012), http://www.newsweek.pl/swiat/separatysci-wygrali-wybory-w-katalonii,98905,1,1.html, 28.12.2020.

Setki tysięcy osób na ulicach Barcelony. Domagaty się uwolnienia więźniów politycznych, https:// wiadomosci.gazeta.pl/wiadomosci/7,114881,23273225, setki-tysiecy-osob-na-ulicach-barcelony-domagally-sie-uwolnienia.html, 12.10.2019. 
Skorzycki M. (2019), Możliwości zakończenia sporu hiszpańsko-katalońskiego w świetle teorii konfliktu Lewisa Cosera, „Studia Europejskie - Studies in European Affairs”, nr 4.

Sytuacja skrajnie poważna. Do tamtej Hiszpanii nie ma powrotu, https://www.tvn24.pl/magazyn-tvn24/ sytuacja-skrajnie-powazna-do-tamtej-hiszpanii-nie-ma-juz-powrotu,119,2155, 28.09.2020.

Szul R. (2015), Regionalizm w Hiszpanii, Mazowsze, Studia Regionalne, Analizy i Studia nr 16.

Torres D., Catalonia elects a new leader, https://www.politico.eu/article/quim-torra-catalonia-electsnew-regional-president/, 25.10.2020.

Quim Torra został nowym premierem Katalonii https://www.gazetaprawna.pl/artykuly/1123548,nowy-premier-katalonii.html, 23.10.2020.

Quim Torra: Spain's top court bans Catalonia leader from office, https://www.bbc.com/news/worldeurope-54328334, 28.10.2020.

W Katalonii: Konieczne drugie referendum w sprawie niepodległości regionu, https://www.tvp. info/44891835/premier-katalonii-konieczne-drugie-referendum-w-sprawie-niepodleglosciregionu, 20.09.2020.

Walka Katalonii o niepodległość, http://demagog.org.pl/wypowiedzi/walka-katalonii-o-niepodleglosc/, 29.09.2020.

\section{Referenda niepodległościowe w Katalonii i ich polityczne znaczenie}

\section{Streszczenie}

Artykuł poświęcony jest przeprowadzonym w 2014 i 2017 roku dwóm referendom niepodległościowym, które zostały przez rząd Hiszpanii oraz hiszpański Trybunał Konstytucyjny uznane za nielegalne. Referenda te były wyrazem dążeń znacznej części Katalończyków do utworzenia własnego państwa. W artykule przedstawiono rozważania dotyczące uwarunkowań historycznych katalońskiego ruchu niepodległościowego, analizy głosowań referendalnych referendum, wpływu pandemii w 2020 na kataloński ruch niepodległościowy. W toku przeprowadzonej analizy przy wykorzystaniu metod: analizy instytucjonalno-prawnej, analizy systemowej oraz historycznej metody genetycznej, wykazano, iż zjawiskiem, które w dużej mirze przyczyniło się do wzrostu nastrojów niepodległościowych w Katalonii były uwarunkowania historyczne, jak i kryzys gospodarczy z 2008 roku. Wszystko to wpływało na wzrost poparcia wśród Katalończyków dla idei niepodległościowej. Dowodem tego były wyniki dwóch referendów niepodległościowych, z których pierwsze przeprowadzone było 9 listopada 2014 r., wzięło w nim udział $2 \mathrm{mln}$ spośród 5,4 mln uprawnionych. Za niepodległością opowiedziało się $80 \%$ uczestników głosowania. Z kolei w referendum 2017 roku wzięło udział 42,3\% z uprawnionych do głosowania $5,34 \mathrm{mln} .90 \%$ z 2,26 mln osób biorących udział w głosowaniu opowiedziało się za niepodległością. $8 \%$ było przeciw. Referenda w Katalonii pokazały, że kwestia dążeń niepodległościowych poszczególnych europejskich regionów wciąż jest aktualna. Nawet kryzys spowodowany pandemią w 2020 roku, separatyści wykorzystali jako nowy argument za uniezależnieniem się od Hiszpanii.

Słowa kluczowe: Katalonia, Hiszpania, referenda niepodległościowe, dążenia separatystyczne, pandemia koronawirusa 
